\title{
The blindness of hindsight: Irish and British poets look back on early fascist Italy
}

\section{Lauren Arrington}

To cite this article: Lauren Arrington (2018) The blindness of hindsight: Irish and British poets look back on early fascist Italy, Irish Political Studies, 33:2, 246-258, DOI: 10.1080/07907184.2018.1454667

To link to this article: https://doi.org/10.1080/07907184.2018.1454667

曲 Published online: 21 Mar 2018.

Submit your article to this journal $\asymp$

Џll Article views: 159

Q View related articles $\asymp$

View Crossmark data $\nearrow$ 


\title{
The blindness of hindsight: Irish and British poets look back on early fascist Italy*
}

\author{
Lauren Arrington \\ Institute of Irish Studies, University of Liverpool, Liverpool, UK
}

\begin{abstract}
In the interwar period, the small town of Rapallo, Italy, was the year-round home of Ezra and Dorothy Pound and a seasonal retreat for W. B. Yeats and George Yeats. The promise of good company, the hope of good weather, and the potential for poetic collaboration drew to Rapallo a number of poets who were influential in shaping twentieth-century poetry. However, Pound's virulent fascism and the Pact of Friendship and Alliance between Germany and Italy (1939) meant that writers were loathe to recognise the degree to which Rapallo was instrumental to late modernist networks. For the most part, biographers have followed suit. This essay attends to memoirs written by Nancy Cunard, H. D., Richard Aldington, and Thomas MacGreevy to illustrate post-war aversions to acknowledging the importance of Rapallo and to demonstrate how writers negotiated their relationship to Pound in constructing their own literary biographies in the shadow of the Second World War.
\end{abstract}

KEYWORDS Autobiography; modernism; Richard Aldington; Thomas MacGreevy; Ezra Pound; W. B. Yeats; Italian fascism; Nancy Cunard; life writing

In Nancy Cunard's memoir, These Were the Hours, she recalls first meeting Richard Aldington 'in Rome, in October 1928, after a party at Ezra Pound's apartment [...] I remember we had a delightful afternoon in Rome, or rather in the strikingly beautiful Roman countryside' (Cunard, 1969, p. 52). Cunard's stress on the words Rome and Roman - the location is repeated three times in the space of four sentences - insists that her encounter with Aldington, a poet, novelist, and classical scholar, occurred in a culturally rich and historically acceptable setting that is easily isolated from the weighty connotations of 1920s Italy. However, as Lois Gordon's biography makes clear, Cunard made regular trips to see Ezra Pound in Rapallo, and Rapallo was where Aldington and his lover, the novelist Brigit Patmore, visited Ezra and Dorothy Pound in February 1929. Cunard's slip may be a simple misremembering since she also errs in dating the publication of Aldington's long 
poem, The Eaten Heart, by Cunard's Hours Press (Gordon, 2007, pp. 121, 123, 180). ${ }^{1}$ Even so, her emphasis on Rome and her repression of Rapallo is indicative of a strong tendency in literary history to situate Pound in a London/Paris modernist network in the 1910s and to imply - if not outright assert - that his move to Italy in 1924 was the beginning of a rapid decline into literary irrelevance, political extremism, and/or mental instability. ${ }^{2}$ Cunard concludes her account of meeting Aldington by quickly reinserting Pound into the frame and then immediately removing him again:

We suddenly both thought of Ezra. Had he recovered from the previous evening? We would investigate at once. Calling at his place we found him, prone, with Dorothy hovering nearby. Ezra chatted, but he had soon to be left alone. (Cunard, 1969, p. 52)

The Second World War cast a generation of writing into the ruins: Pound's political allegiances became undeniable, and writers felt compelled to account for their proximity to him and their presence in provincial Italy during Mussolini's regime. Aldington and Patmore were in Rapallo only once, in February 1929; Thomas MacGreevy visited W. B. Yeats and George Yeats in Rapallo at Christmastime 1928, just prior to Aldington's visit. Although their visits do not appear to have been concurrent, Rapallo should be credited with bringing Aldington and MacGreevy together. Much to W. B. Yeats's disparagement, while MacGreevy was in Italy, he 'made great friends with Ezra' (Yeats to Lady Gregory, 28 December 1929; in Kelly, 2002, Acc \#5206). Yeats grumbled in a letter to Lady Gregory, 'I thought him [MacGreevy] solider \& richer in all his thought' (Yeats to Lady Gregory, 28 December 1928, CL InteLex Acc \#5206). Soon after MacGreevy left Rapallo, he reflected, in a letter to George Yeats, on the impact of meeting Pound:

I've had lots to think about as a result of my visit to you. It was terribly worth while to me and, needless to say, enjoyable as well. Needless to say I am upset as a result of it too. I want to be 'nothing so much as' a starving poet and am making all sorts of secret plans with a view to achieving that ambition [... .] There is no one at the moment only Ezra - my latest hare. But if I had done nothing at Rapallo but get hold of your copies of the cantos it would have been worth the voyage. ${ }^{3}$

MacGreevy concludes, 'cordial remembrances and respects to the Pounds. I'll write to Ezra when I have seen his friends' (MacGreevy to George Yeats, 13 January 1929; Thomas MacGreevy Archive). These 'friends' almost certainly were Aldington and Patmore, who were living in Paris and were due to visit Rapallo in a few weeks.

In MacGreevy's essay, 'Richard Aldington As Friend,' published in 1965, he writes that it 'was probably 1928' that the pair met; however, 1929 seems to be a more correct dating, since their correspondence begins with conversations about the sales of Aldington's Death of a Hero and the progress of 
Aldington's next novel, The Colonel's Daughter. ${ }^{4}$ In MacGreevy and Aldington's memoirs, they give different settings for their first encounter; Aldington puts it in a Parisian café, while MacGreevy lends their friendship an even stronger modernist genealogy, citing its beginning in the hospitable surrounds of James Joyce's apartment. ${ }^{5}$ MacGreevy's probable infelicity, like Cunard's, avoids tainting his relationship with Aldington by association with Pound through the Rapallo matrix.

Ezra Pound's one-time fiancé and Richard Aldington's first wife, the poet Hilda Doolittle (H. D.), was never in Rapallo, yet the place exerts strong psychic pressure on her past with Pound. ${ }^{6}$ In her apologia, End to Torment: a memoir of Ezra Pound (the title of which speaks more of her coming to terms with herself than with Ezra), she writes about visiting a Venetian church with Pound shortly following her marriage to Aldington:

Years afterwards, I went again and I carried the votive card of Santa Maria that the sacristan had given me, in my handbag, with another (St. Mark's) token picture, during the [World] War II years in London. Ezra was in Rapallo, as we all know. (H. D., 1979, p. 6)

Speaking on behalf of Pound's friends, she writes,'I can not say that any of us are satisfied with the equation, Fascist-party-line-by-short-wave-to-America + Poet = Senilität. There is, as I myself felt [...] the hint of a crime passionnel, for which [...] "no jury" as the phrase has it, "will convict"' (H. D., 1979, p. 32).

H. D. was compelled to write End to Torment after reading the essay, 'A Weekend with Ezra Pound,' about the young scholar David Rattray's visit to St Elizabeth's, which was published in The Nation in 1957. ${ }^{8}$ Aldington sent $H$. D. the article; she returned it, asked for it again, and offered to return it a second time, but Aldington told her to keep it, saying, 'It is such a welcome change to have [Pound] reported as a human being, and not as journalist's abstraction or political "cause"' (H. D., 1979, p. 9). By the mid-1950s, Aldington's feelings about Pound had mellowed, but in his own accounting for Ezra, the memoir Life for Life's Sake, which was published in the midst of the Second World War, Aldington denies culpability for the time he spent in Italy, and he holds Pound in deep contempt: 'He is a Rapallo troglodyte, suffering from the mental indigestion following on a feast of fascism plus the tootoo solid hokum of Social Credit. Que diable allait-il faire dans cette galère' (Aldington, 1941, p. 106). The quote from Moliere - What the devil was he doing in that gallery? - applies, just as aptly, to Aldington himself.

Born nearly a decade before the Auden generation, Aldington takes pains to distance himself from the writers of the Thirties; in Life for Life's Sake, he reflected:

the 1920s formed a brilliant but anarchic period fully deserving both in a bad and good sense its favourite adjective, 'amusing.' The ideals and differences of artists were largely aesthetic only. In reaction, the 1930s gave themselves 
up to political fanaticisms, and were consequently duller and less sincere - they all quacked what the big doctrinaire duck trumpeted. Moreover, the decade became more and more clouded with menaces and fears, so that many artists were tempted beyond the boundaries of their legitimate activities; and in some countries were forced over them. (Aldington, 1941, pp. 323-324)

In W. H. Auden and John Garrett's anthology, The poet's tongue (1935), they are careful to explain that poetry as action is not didacticism:

Poetry is not concerned with telling people what to do, but [...] perhaps making the necessity for action more urgent and its nature more clear, but only leading us to the point where it is possible for us to make a rational and moral choice. (Auden \& Garrett, 1935, p. ix; also quoted in Hynes, Auden Generation, 14) ${ }^{9}$

Yet for Aldington, the idea of poetry as action was too similar to Pound's vision of the poet as political advisor. In Life for Life's Sake, Aldington goes so far as to describe Imagism - the poetic movement of which he was a prime instigator as a totalitarian takeover:

I don't claim to be the Fuehrer of the Imagists [.... The fame or otherwise of Ducedom must go to Ezra, who invented the 'movement' [... .] Whenever Ezra has launched a new movement - and he has made such a hobby of it that I always expect to find one day that Pound and Mussolini are really one and the same person - he has never had any difficulty about finding members. He just called on his friends (Aldington, 1941, pp. 133, 135)

Aldington uses the excuse of age to exonerate himself: 'I was five years younger than the next youngest member of the group, and when the first Imagist poems appeared I was all of twenty' (1941, p. 133).

Dismissing as youthful folly the considerable body of work he had written before the First World War, Aldington presents the war as a coming-of-age rite, and he implies that Pound's avoidance of conscription had stunted his poetic growth. (This was not far off Pound's own worry that his lack of experience of war hampered his ability to write effectively about it). ${ }^{10}$ In language suggestive of H. D.'s psychoanalytical obsession, Aldington chastises Pound as 'one of the problem children of modern poetry.' He cites Ford Madox Ford, who despite being twelve years older than Pound, had enlisted in the British Army and nearly died at the Somme: 'Hueffer used to say that Ezra is so ignorant of the English language that it is impossible to understand him' (Aldington, 1941, p. 104). Aldington similarly thought that Yeats was unable to comprehend how the First World War had changed poetry. He complained in a letter to MacGreevy from 1931:

We helped to carry the world on our bayonets at twenty, and we are entitled to a certain respect in consequence. We passed beyond life and death, beyond good and evil, and a man like W.B. should be able to tell the difference [... .] It is not a question of our gifts but of experience; we are men, while they are eternally 
adolescent. Discuss the same unto W.B., firmly, when you next see him. (Aldington to MacGreevy, 31 May 1931, TCD MS 8107 [46])

Pound's failure to serve in the First World War still rankled as late as 1959, after Aldington (according to H. D.) had arrived at a more charitable view. That year, Aldington wrote to MacGreevy about the newly published Casebook on Ezra Pound, which compiled 'evidence' for and against Pound's indictment for treason. He admitted to MacGreevy,

I think he was too crazy to realise what he was saying [in the broadcasts from Rome], but one of them is a distinct appeal (or order) to the US troops in Africa to stop fighting! 'Pétan was defending Verdun while Blum was defending a bidet,' says he [the quote is from the Pisan Cantos]. Well, and what was Ezra doing in 1914-18? Dodging the draft!. (Aldington to MacGreevy, 4 June 1959, TCD MS 8107 [103]) ${ }^{11}$

Gertrude Stein's invention of 'the Lost Generation' to describe writers who made their careers after the First World War created the terms by which Aldington and MacGreevy could define their comradeship as poets and their differences to their peer, Ezra Pound, and predecessor, W. B. Yeats. ${ }^{12}$ Aldington and MacGreevy's affinity illustrates how literary generations are not dependent on the proximity of birthdays and death dates but are created by writers who sense a commonality in experience and aesthetics. ${ }^{13}$ In their autobiographical writing as well as their writing about other poets, Aldington and MacGreevy both situate Yeats in the fin de siècle, rather than acknowledging his life as a 'modern' who was their contemporary. Aldington comes close to caricature in his depiction of a bumbling, esoteric, and naïve elder who had the 'curious trait' of 'misplaced intellectual loyalty':

Every influence, however distant, which had come into his poetical life had to be cherished and somehow reconciled with all the later influences and Yeats's own continuous developement [sic]. He seemed unable to take the more rational position of admitting frankly that such people had once been valuable to him, but that while he was grateful to them he had gone on to something new. This persisted even in Yeats's later years when he made that remarkable recovery and wrote some of the most beautiful lyrics of our time. (Aldington, 1941, p. 107)

For Aldington, Yeats's age, eccentricity, and achievement excuse his attachment to outmoded, irrational, or unethical ideas.

The title of MacGreevy's (1966) essay, 'W. B. Yeats: a Generation Later', alludes to the sense that a new generation was created with Yeats's death in January 1939. What first appear to be idiosyncratic points of focus in MacGreevy's essay reveal themselves, on closer examination, as attempts to justify Yeats's writing from the 1930s, after the Second World War made the aesthetics of violence untenable. For example, MacGreevy chose to write about one of Yeats's lesser known plays, The King of the Great Clock Tower (1934), 
and in his analysis, he stresses its similarity to Oscar Wilde's symbolist play Salome (1893). In Yeats's published notes to Clock Tower, he acknowledges the proximity of his work to Salome, but he emphasises that in Wilde's play, 'the dance is before the head is cut off' (Variorum Edition of the Plays, 1966, p. 1010). Yeats deliberately diminishes fin de siècle associations and calls attention to Clock Tower's use of music, dance, and costume as characteristic of Japanese Noh drama. Tellingly, he began to experiment with the Noh form after spending three winters with Ezra Pound in Stone Cottage, in east Sussex, from 1913 to $1916 .^{14}$

Yeats strongly alludes to Pound in his commentary on The King of the Great Clock Tower, which was included in the Cuala Press (1934) and Macmillan (1935) editions of the play. There, Yeats describes going on 'a considerable journey [i.e. to Rapallo] partly to get the advice of a poet not of my school who would, as he did some years ago, say what he thought' (Variorum Edition of the Plays, 1966, p. 1309). This poet 'would not speak of art, or literature, or of anything related to them' and 'would talk of nothing but politics,' saying all 'modern statesmen were more or less scoundrels except "Mussolini and that hysterical imitator of his Hitler"' (Variorum Edition of the Plays, 1966, pp. 1309-1310). ${ }^{15}$ Yeats continues, 'When I objected to his violence he declared that Dante considered all sins intellectual [... .] He took my manuscript and went away denouncing Dublin as "a reactionary hole" because I had said that I was re-reading Shakespeare' (Variorum Edition of the Plays, 1966, p. 1310). In Yeats's preface to his verse play, A Full Moon in March (a substantial reworking of Clock Tower), he describes The King of the Great Clock Tower as a play in prose; in fact, it is written for the most part in blank verse, showing Yeats's debt to the English poetic tradition. Yeats's use of Shakespearean form is what Pound derogated as a 'reactionary' turn, and the episode may have informed Pound's 1958 satire of Yeats's self-elegy: 'Neath Ben Bulben's buttocks lies, / Bill Yeats, a poet twoice the soize / Of William Shakespear, as they say / Down Ballykillywuchlin way'. ${ }^{16}$

Yeats and Pound's disagreement in 1934 looms over MacGreevy's essay, possibly because MacGreevy was probably one of the poets whom Yeats approached for a second opinion, 'until,' Yeats writes, 'I was like Panurge consulting oracles as to whether he should get married and rejecting all that did not confirm his own desire' (Variorum Edition of the Plays, 1966, p. 1310). MacGreevy's emphasis on the echoes of Salome in Clock Tower has the effect of detracting from Yeats's violence, which far exceeds the beheading in Wilde's drama. In Clock Tower, the King orders the beheading of the Stroller (the equivalent of Salome's John the Baptist figure), but the King also desires to murder his wife the Queen. The King's subconscious impulse is articulated through ventriloquism, in lines that evoke the depiction of the rape in 'Leda and the Swan.' ${ }^{\prime 7}$ Surprisingly, MacGreevy writes that of all Yeats's drama, he prefers the equally obscure play, The Unicorn from the 
Stars (1907). In the notes to Unicorn, which MacGreevy does not cite, Yeats states that it was a play that 'had to be done without hurry or violence' (Variorum Edition of the Plays, 1966, p. 712). The subtle contrast that MacGreevy draws between Clock Tower and Unicorn not-so-subtly exculpates Yeats from association with a violent, fascistic aesthetic. MacGreevy drives his point home:

That play [Unicorn] was written in 1908 twenty-five years before Adolf Hitler came to power in 1933, but when I saw it played in London in 1940 it seemed to me so cogent to the European situation of the day that (apart needless to say from the beauty of the treatment) it might have been commissioned from some Allied literary propagandist. (MacGreevy, 1966, p. 5)

If the punitive treaties imposed after the First World War delineated the political fault lines of the Second, then the roots of some of the most harrowing events of the 1930s and 1940s can be traced back to the cultural nationalism that pervaded the late-nineteenth-century Europe. Even so, due to factors including a seductive narrative of Irish oppression and liberation, the lumping in of Ireland with other 'small nations' during and after the First World War, the creation of the Irish Free State, and the Republic of Ireland's neutrality during the Second World War, the Irish Revival has not come under the same scrutiny that has been applied to German and Polish cultural nationalisms. So, in 1966 - the fiftieth anniversary of the Easter Rising - MacGreevy could write assuredly, without making himself or his subject vulnerable to aspersions, that Yeats 'accepted the idea that a distinctive cultural heritage implies distinctive nationhood' (MacGreevy, 1966, p. 3).

MacGreevy still had to account for Yeats's belief in an intellectual aristocracy that was preserved by the Irish Protestant landed class, and drafts of 'W.B. Yeats: a Generation Later' show him struggling to construct an adequate defence (see TCD MacGreevy MS 8000/6 [12] and 8,000/6b [10-11]). He decided to tackle head-on Yeats's 1924 Tailteann speech, in which Yeats had praised and quoted from Mussolini (for a discussion of this speech, see Foster, 2003, p. 265). MacGreevy explained Yeats's attitude and attempted to justify his own inaction:

In his lecture, W.B. put forward these two [i.e. Swift and Burke], and George Berkeley with them, as reactionary (which to him, in his political innocence, meant merely orderly) counterblasts to the revolutionaries. Politically, W.B. was as innocent as most laymen. About 1923 or 1924 he told me he believed that Mussolini represented the rise of the individual man as against what he considered the anti-human party machine. I was most distrustful about 'Il Duce' but I did not know enough then to answer that Mussolini was believed to be in the hands of an economically, and therefore politically, powerful group of men in Italy. W.B. did know enough abstract history, to know that it is axiomatic that revolution has to be followed by reaction. The Irish ascendency as a whole had tended 
to be selfishly reactionary [... .] W.B. would insist on trying now to provide the ascendency with a group of philosophic avatars, Swift and Berkeley and Burke, who were reactionary but not selfish. (MacGreevy, 1966, p. 9)

It is tempting to give MacGreevy the benefit of the doubt about whether Yeats knew the meaning of 'reactionary;' however, in a letter to Lady Gregory in 1913, Yeats had deployed the term with biting accuracy: 'I hear that Prof Trench is a candidate for Dowden's place. I hope he does not get it as a protestant bigot is the last thing desirable in TCD \& his ideas of teaching seem to me reactionary' (Kelly, 2002, Acc \#2153). Yeats also used 'reactionary' to great effect against Shaw (Gould, Kelly, \& Toomey, 1997, p. 500).

W. B. Yeats's death, in the January before the Second World War erupted in September, eased MacGreevy's claim of 'political innocence,' but there remains the clear and persistent problem of Yeats's most extreme pronouncements - not only the 1924 Tailteann speech but also the 1935 'Commentary on a Parnellite at Parnell's Funeral.' MacGreevy turns Yeats's strident support of constructive authoritarianism in that essay into an unsolved proposition:

The question was whether, in the new order of things created in Ireland by the Treaty, ascendancy people as a whole could be persuaded to play a constructive part. That could help towards the ultimate realisation of the unified and cultured Ireland of W.B.'s dreams. (MacGreevy, 1966, p. 9) ${ }^{18}$

Couching Yeats's arguments as ineffective, MacGreevy claims they are also innocuous: 'There is little evidence to show what influence his famous lecture has had on the ascendency' (MacGreevy, 1966, p. 9). This claim of political ineffectiveness would also be made by Basil Bunting, with regard to Ezra Pound.

In 1932, two years before W. B. and George Yeats gave up their apartment in Rapallo, Aldington and MacGreevy corresponded about the impending danger in Europe. In June, Aldington warned of 'a general collapse somewhere between July and late September' and advised that MacGreevy and 'Sam [Beckett] would be wise to get back to Ireland this summer. Every government will have to try to ration its nationals, but it won't be pleasant to be in a foreign country, especially if there are moratoriums flying about' (Aldington to MacGreevy, 15 June 1932, TCD). Near the end of September, Aldington wrote again, suggesting that MacGreevy had been (and perhaps still was) a little naïve:

Italy is so spoiled and one gets so weary of Fascist brag and interference. They've killed the old Italy - one more sweet benediction of that blessed war. And you will have seen that Germany has failed as a democracy and has gone reactionary. They've begun by a purity campaign, which always means preparation for War [... .] War was nearer than you perhaps realise. I saw what was happening in Italy, and we were prepared to leave at an hour's notice. Those Italians in 
power now are shits, real shits, and a most disturbing force in Europe. (Aldington to MacGreevy, 21 September 1932, TCD)

Aldington's advice may have been the deciding factor in MacGreevy's taking leave of Paris for home - first going back to his native Tarbert in County Kerry, then to Dublin for the whole of 1933, before moving to London where he stayed long enough to help remove paintings from the National Gallery during the Blitz.

In 1955, MacGreevy was awarded the Order of Merit of the Italian Republic by President Luigi Einaudi; the same year, Italy and Ireland joined the United Nations. MacGreevy was shocked when, a mere three years later, Ireland's long-standing Taoiseach, Eamon de Valera, proposed to replace the electoral system of proportional representation with the single non-transferable vote (the British 'first past the post' system). MacGreevy responded angrily with the essay 'Strong and Able Government Versus Good Government' in which he poured out his wrathful opinions on Irish politics and Italian recent history:

The Irish people also have a shrewd idea of what the influences were that made Eamon de Valera commit Ireland so gratuitously to the recognition of the Italian Black and Tannery in Abyssinia [i.e. the Catholic Church .... .] The influences to which De Valera has submitted in the case of the Abyssinian scandal are now being brought to bear on him with a view to the repression of minorities at home. (TCD MS 8003/10). ${ }^{19}$

He continued,

'Strong and able' government means the tyranny of authority imposed by unproductive capital from above, not derived from the productive life of the masses below. Ask the representatives of any of the progressive minorities who survive from the days of relative liberty in Germany or Italy. They know. (TCD MS 8003/10 [2])

MacGreevy's Marxian language resonates with the Republicanism that he had espoused in the 1920s, but his essay is also in tune with a sympathetic interpretation of Yeats's 'Commentary on a Parnellite.' In that essay, Yeats describes the 'Garrison [class], a political party of Protestant and Catholic landowners, merchants and officials' as isolated from 'the people they thought unfit for self-government' (Variorum Edition of the Plays, 1966, p. 833-834). MacGreevy's architecture of the state also chimes with 'A Race Philosophy,' Yeats's most extreme utterance undiluted by a persona. ${ }^{20}$ 'A Race Philosophy' prioritises the individual first and the family second as the basis for sound government (following the same structure set out in Ezra Pound's 1929 translation of Ta Hio: the Great Learning). In Yeats's lexicon, the folk and the 'family' represented the same ideas that MacGreevy describes as 'the productive life' below. Both Yeats and MacGreevy conceive of productive government as being in harmony with the spiritual life of the nation, which draws its strength from its 'minorities' (i.e. Protestants) as well as its Catholic 'masses.' These 
similarities suggest that, near the end of MacGreevy's life, at least, he had drawn closer to Yeats's ideal state, which MacGreevy reconstructed by attempting to divorce it from its fascistic associations. ${ }^{21}$

Contemporary biography and literary criticism has, in the main, followed the lead of the Rapallo poets, downplaying their interactions with Pound and thereby distancing them from his toxic politics. Memoirs by Cunard, H. D., Aldington, and MacGreevy illustrate how the post-war problem of accounting for Rapallo has obscured its instrumental role in forging relationships and collaborations that exceed the interwar period and the Italian context, extending through, and changing, twentieth-century poetry. Furthermore, Aldingon and MacGreevy's self-conscious creation of a literary generation, which they defined by participation in the First World War and thereby claimed to be astute about the Second, enabled them to construct a genealogy that positioned W. B. Yeats as a wise, albeit eccentric, ancestor, and excluded Ezra Pound in a No Man's Land, where his ghost still often lingers.

\section{Notes}

1. Aldington and Patmore also visited Pound in Rome, but that was in 1930, a year after The Eaten Heart was published by the Hours Press. Cunard incorrectly dates the publication of The Eaten Heart, as 'about a year and a half before [Aldington's] greatly acclaimed war novel, Death of a Hero appeared'. However, Death of a Hero was also published in 1929.

2. Richard Burton writes in his biography of Basil Bunting, 'Pound's incarceration in St Elizabeth's psychiatric hospital after the Second World War effectively finished him off as a poet and, more damaging yet, as an editor' (2013, pp. 260-261). More recently, Swift (2017) shows how Pound continued to be an important touchstone for mid-century poets, including Elizabeth Bishop and Robert Lowell. David Moody's Ezra Pound: Poet (2015) which runs to three volumes has recovered in extensive detail Pound's vibrantand varied literary and political pursuits in Rapallo.

3. Geoffrey Phibbs was married to the artist Norah McGuinness (who designed scenes for the Abbey Theatre); in a letter to George Yeats on 9 March MacGreevy reports gossip that Phibbs has left McGuinness for Laura Riding and was living with her in London, with Robert Graves ('as No 1 lover') still occupying the house; that letter concludes with 'love to E.P. as well as yourselves.'

4. Susan Schreibman follows MacGreevy's dating of his meeting with Aldington, without presenting corroborating evidence; see Schreibman (1991, p. 154).

5. MacGreevy writes, 'It was the very Irish setting of the salon at James Joyce's apartment [... .] The walls were hung with admirable contemporary portraits of Joyce and his family [...] and also with portraits of ancestors'; 'Thomas MacGreevy' in Kershaw and Temple (1965, pp. 52-64); Aldington (1941, pp. 342343). Whelpton opts for the Joycean locale for Aldington and MacGreevy's meeting but provides no reference (2014, p. 316); also see Thomas MacGreevy, 'Richard Aldington As a Friend' (TCD MS 7996/1).

6. H. D. wrote about the figure of the fisherman in Pound's poem, 'The Goodly Fere': 
He is the center of some kind of communal integration-disintegrating toward rebirth, as personally Ezra severed me (psychically) from friends and family. If having been severed, painfully reintegrated, we want only to forget the whirlwind or the forked lightning that destroyed our human, domestic serenity and security, that is natural. (H. D., 1979, p. 48)

7. H. D. was engaged to be married to Pound when he left the US for London, where he soon proposed to Dorothy Shakespear, daughter of Olivia Shakespear (who was W. B. Yeats's close friend and first lover); after H. D.'s break-up with Pound, she married Aldington, but their marriage disintegrated under the pressures of the First World War and their loss of a child. Aldington had a long and tortuous affair with Brigit Patmore, who was with him in Paris and Rapallo in 1929; in 1938, following his divorce from H. D. (from whom he was long estranged), he married Brigit Patmore's former daughter-in-law, Netta McCullough.

8. Rattray was an undergraduate at Dartmouth; he went on to have an esteemed career as translator and poet, with degrees from the Sorbonne and Harvard. His essay 'Weekend with Ezra Pound' is reprinted in O'Connor and Stone (1959, pp. 104-117).

9. Aldington and Garrett include in their anthology five poems by Yeats, but none by Aldington, Pound, or Basil Bunting.

10. Longenbach writes, 'although Pound felt the impulse to address the European conflict in verse, he worried that without any firsthand experience of the war, his poetry would seem facile and opportunistic, the emotion literary and false' (1988, p. 115).

11. See Canto LXXX in Cantos of Ezra Pound (1996, p. 514). This canto would have been of particular interest to Aldington since it also contains some of Pound's most famous lines on Yeats: 'the problem after any revolution is what to do with / your gunmen / as old Billyum found out in Oireland / in the Senate, Bedad! Or before then / Your gunmen thread on moi drreams' (p. 516).

12. Pound sometimes saw himself as Aldington's peer; he signed a letter, 'yr. disobliged and disobt. shall we say "contemporary" (no other relationship being conceivable)'. Pound to Aldington (31 March 1928, HRHRC Pound/Aldington 5.5). In the next letter in the file, Pound chastises Aldington for not writing a more favourable review of Pound's study of Remy de Goncourt, and changes their generational relationship: 'meditate on yr prore ole farver's wordz.'

13. Marius Hentea compares Henry Green and H. E. Bates, for example, as proof against 'generation' as a reliable means of constructing literary history (2013).

14. For a discussion of these three winters, see Longenbach's Stone Cottage: Pound, Yeats, and Modernism (1988). For Clock Tower and its successor A Full Moon in March as Noh plays, see my essay "Fighting Spirits" (2018).

15. See also Foster (2003, p. 500). Yeats recorded Pound's other criticisms in a private notebook: the play was written in 'nobody language,' which was something Yeats thought he could 'remedy;' see Ellmann (1966, p. 491).

16. Pound's satire is quoted in Ellmann (1966, pp. 470-495, 492).

17. The Queen's verses are ventriloquised by the Second Attendant, in a psychological turn that anticipates the dramatisation of the interior in later modernist drama; the song evokes lines from 'Leda and the Swan' in its equation of death and sexual consummation: 'He longs to kill / My body, until / That sudden shudder / And limbs lie still' (Variorum Edition of the Plays, p. 1000); 
compare, 'A shudder in the loins engenders there / The broken wall, the burning roof and tower / And Agamemnon dead' in 'Leda and the Swan.'

18. See 'A Commentary on a Parnellite at Parnell's Funeral' (1935) and Variorum Edition of the Poems of W.B. Yeats (1966, pp. 833-834).

19. The typescript is undated. Rhiannon Moss writes that the piece was 'probably written in the late 1930s' but the proposed amendment that MacGreevy is addressing was not brought before the Dáil until 1958. For Moss's dating, see 'Thomas MacGreevy, T.S. Eliot and Catholic Modernism in Ireland,' in Keown and Taaffe (2009, pp. 131-144, 141).

20. See, for example, the Old Man's fascistic pronouncements in On the Boiler, the essay that accompanied W.B. Yeats's play Purgatory.

21. The essay was published a year before MacGreevy's death in 1967.

\section{Disclosure statement}

No potential conflict of interest was reported by the author.

\section{References}

Aldington, R. (1941). Life for life's sake: a book of reminiscences. New York, NY: Viking Press.

Alspach, R. K. (1966). The variorum edition of the plays of W.B. Yeats. London: Macmillan. Arrington, L. (2018). Fighting spirits: Yeats, Pound, and the ghosts of the winding stair (1929). In Warwick Gould (Ed.), Yeats Annual (pp. 269-294). Cambridge, UK: Open Book.

Auden, W. H., \& Garrett, J. (1935). The poet's tongue. London: G. Bell \& Sons.

Burton, R. (2013). A strong song tows us: The life of Basil Bunting. Oxford: Infinite Ideas.

Cunard, N. (1969). These were the hours: Memories of my hours press, Réanville and Paris, 1928-1931, ed. with a foreword by Ford, H. Carbondale: Southern Illinois University Press.

Ellmann, R. (1966). Ez and Old Billyum. Kenyon Review, 28(4), 470-495.

Foster, R. (2003). W.B. Yeats: A life. Vol. 2. Oxford: Oxford University Press.

Gordon, L. (2007). Nancy Cunard: Heiress, muse, political idealist. New York, NY: Columbia University Press.

Gould, W., Kelly, J., \& Toomey, D. (Eds.). (1997). Collected letters of W.B. Yeats: Volume II, 1896-1900. Oxford: Clarendon Press.

H. D. (1979). End to Torment: A Memoir of Ezra Pound (N. H. Pearson \& M. King, Eds.). New York, NY: New Directions.

Hentea, M. (2013). The problem of literary generations: Origins and limitations. Comparative Literature Studies, 50(4), 567-588.

Kelly, J. (Gen. Ed.) (2002). The collected letters of W.B. Yeats. Oxford: Oxford University Press [InteLex Electronic Edition].

Keown, E., \& Taaffe, C. (Eds.). (2009). Irish modernism: Origins, contexts, publics. Bern: Peter Lang.

Kershaw, A., \& Temple, F. (Eds.). (1965). Richard Aldington: an Intimate Portrait. Carbondale: Southern Illinois University Press.

Longenbach, J. (1988). Stone cottage: Pound, Yeats, and modernism. Oxford: Oxford University Press.

MacGreevy, T. (1966). A generation later. University Review, 8, 3-14.

Moody, D. (2015). Ezra Pound: Poet. 3 Vols. Oxford: Oxford University Press. 
O'Connor, W. V., \& Stone, E. (Eds.). (1959). A casebook on Ezra Pound. Cornwall, NY: T. Y. Crowell.

Schreibman, S. (Ed.). (1991). The collected poems of Thomas MacGreevy. Dublin: Anna Livia Press.

Swift, D. (2017). The Bughouse: The poetry, politics, and madness of Ezra Pound. London: Harvill Secker.

Thomas MacGreevy Archive. Retrieved from http://www.macgreevy.org

Whelpton, V. (2014). Richard Aldington: Poet, soldier and lover, 1911-1929. Cambridge: Lutterworth Press. 